\title{
Slow Tourism at the Caribbean's Geographical Margins
}

\author{
BENJAMIN F. TIMMS \& DENNIS CONWAY
}

\begin{abstract}
The Caribbean tourism industry owes much of its success to beneficial geographical site and situation factors. Yet these geographical advantages have also contributed to the mass tourism-related pressures of economic dependency, social division and environmental degradation. We argue geographically marginal locales in the Caribbean have the potential to develop alternative tourism models that ameliorate these negative repercussions. With its conceptual roots originating from the slow food movement and theoretically rooted in Herman Daly's 'soft growth' development, we propose slow tourism as a viable soft growth model that is a more culturally sensitive and sustainable genre of alternative tourism. This new model and its locational appropriateness appears eminently suitable since it diversifies and revitalizes mature tourism offerings, redirects tourism away from 'hard growth' maxims, and thereby contributes to more sustainable tourism ensembles. In a maturing industry that requires innovation, revitalization and significant change in offerings if it is to survive and prosper, we argue the best places to promote slow tourism lies in the Caribbean's overlooked geographical margins where diversity and authenticity still persist.
\end{abstract}

Key Words: Caribbean, slow tourism, alternative tourism, sustainable development, geographical marginality

\section{Introduction}

The Caribbean tourism industry owes much of its success to beneficial geographical site (amenity) and situation (accessibility) factors, both of which have contributed to tourism's position as the dominant economic sector in the region. Traditionally the favourable site factors for islands in the Caribbean have been described as the tropical 'three S's' of sunlight, sand and sea so sought after by mass tourists from temperate latitudes (Davenport \& Jackiewicz 2008). Situation factors refer to the accessibility of Caribbean destinations for these same tourists, noting the relative geographical proximity to tourism markets in North America and Western Europe in comparison to other tropical tourist destinations (Dodman 2009). 
Having such a geographically advantageous tourism industry holds many development benefits, including being a major source of foreign exchange earnings, provider of employment, and stimulator of linkages with other sectors of island economies, such as agriculture (Timms 2006; Rhiney 2009). However, these positive geographical characteristics and the resultant embracing of mass tourism by most Caribbean islands have also resulted in an assortment of economic, social and environmental problems. Amongst them is the continuation of economic dependency that has plagued Caribbean societies since the colonial plantation era, through post-colonial transitions and into the present post-1980s neo-liberal crisis (Conway \& Timms 2003; Duval \& Wilkinson 2004; Pattullo 2005). In its most recent neo-liberal form, based on liberalized trade and privatization, this legacy renders island economies dependent. Also, because each competes intra-regionally for foreign tourist markets, their vulnerability to the vagaries of the global economic system increases, while their autonomy is diminished. Further exacerbating these economic concerns are high levels of capital leakage, whereby foreign ownership or control of tourism ensembles repatriates profits and sources inputs, such as food and management, from abroad. As a result, foreign exchange earnings are reduced and extra-sectoral linkages continue to determine Caribbean tourism's development paths (Momsen 1998).

Furthermore, the region's continued incorporation into a global order in which mass tourism adheres to the dictates of neo-liberal capitalist policies of de-regulation has resulted in a lack of concern for social equity and social justice. This has produced unacceptable social divisiveness and a widening of inequalities and class-stratification in many Caribbean insular societies that have reached advanced states of tourism penetration (Thomas 1991; McElroy \& de Albuquerque 1998; Potter et al. 2004). Other negative social impacts include the spread of cultural imperialism with the demonstration effect altering local cultural norms and reorientating household resource allocations toward consumptive, rather than productive, activities. In relation, tourism also contributes to the rise of hedonistic activities, such as gambling, drugs and prostitution (Maingot 1994) while replicating the master-slave legacy of the plantation era through the tourist-servant relationship (Potter et al. 2004).

Tourism has been implicated in the creation, or exacerbation of, a host of environmental problems. Long-haul airline travel has recently come under scrutiny, as it is the greatest contributor of carbon dioxide emissions of any tourism activity (Hall 2009). Unacceptable levels of environmental degradation of coastal zones have accompanied the unfettered embracing of mass tourism by Caribbean small-island states, thereby increasing their vulnerability to natural hazards, such as floods, hurricanes and even volcanic eruptions (Commonwealth Secretariat 1991; Watts 1995; Walsh 1998; Baldwin 2000; Pelling \& Uito 2001; Boruff \& Cutter 2007; Wilkinson 1999). In addition, many islands may have over-reached, or are approaching, their tourism carrying capacity, as increased influxes of wealthy resource-intensive tourists have taxed Caribbean water, food and waste disposal capacities. The result has been a whole-scale transformation of both the natural and cultural landscapes of Caribbean 
islands dependent on mass tourism, which in turn threatens the very geographical site factors upon which tourism in the Caribbean depends.

In light of the many concerns just noted, there has been a necessary re-evaluation of mass tourism in the Caribbean from a sustainability perspective (Conway \& Timms 2003; Duval \& Wilkinson 2004; Weaver 2004; Pattullo 2005). Here we not only join these critics but go a step further to argue that geographically marginal locales in the Caribbean - both regionally and internally - have considerable potential as appropriate sites to develop sustainable tourism models that minimize, or avoid altogether, mass tourism's negative repercussions while maximizing local community benefits and contributing to overall sustainable development. Underlying this challenging reappraisal of conventional Caribbean tourism, we also propose that future tourism in the region be more sustainable by concentrating on quality considerations and being risk-averse through a community development focus on participatory planning, co-management and small-scale tourism - not tourism growth and development perse.

To achieve this goal we propose slow tourism as a viable model for the Caribbean's geographical margins with the same development potential as the philosophically related slow food movement (Conway \& Timms 2010). More broadly referred to as the slow movement, it is the antithesis to the fast and unsustainable life of modern industrial society through advocating a return to a more sustainable slow life based on savouring experience, rather than maximizing consumption. Like its precursor, the slow tourism model we propose for geographically marginal locales in the Caribbean offers a more sustainable tourism product that is less alienated (and alienating), more culturally sensitive, authentic and a better-paced experience for hosts and tourists alike. The goals we set for our slow tourism model coalesce with those of other alternatives to mass tourism, such as eco-tourism, community tourism and pro-poor tourism (amongst others) in that they are, or should be, all developmentfrom-below initiatives that have sustainability built into their praxis. However, slow tourism advances the alternative tourism genre by adopting Herman Daly's concept of 'soft growth' where emphasis is placed on advancing development (quality) instead of promoting physical growth (quantity) (Daly 1990; 1991; 2008). As such, slow tourism promotes equitable economic and social benefits to local communities, limits environmental pressures, and serves the growing demand for responsible tourism sought after by a more consciously motivated cohort of travellers - all hallmarks of a progressive sustainable development model for the Caribbean.

This paper first focuses on the contributions of geographical site and situation factors to mass tourism's development in the Caribbean and its most attractive coastal zones. Paradoxically, these same factors that contributed to the industry's early 'hard growth' development also brought about geographical marginality in interiors and less-accessible coastal and insular regions, which nowadays can serve as advantageous locales for fostering alternative tourism efforts that follow sustainability maxims. Accordingly, in the third section we propose slow tourism as a 'soft growth' 
alternative model that embraces the best notions of progressive 'development-frombelow' theories and environmental sustainability objectives (Daly 1990; 1991; Conway 1993; Klak 2007). We view slow tourism as a derivative of the globally successful slow food movement, since it adheres to similar philosophical tenets and follows soft growth principles in stressing 'quality of life' considerations as opposed to the 'fast and furious' pursuits of contemporary practices in too many peoples' everyday lives.

In an industry that has undergone constant change from inception to maturation in its passage through Butler's (1980; 2004) Tourism Area Life Cycle (TALC), the need to maintain its competitiveness and undertake upgrading strategies to revitalize its offerings (ECLAC 2008), slow tourism offers a new vision and a new alternative perspective to sustain and maintain Caribbean tourism in the future. It may well be that the best locales to find and promote such an alternative tourism model are the overlooked geographical margins where diversity and authenticity exist and opportunities await discovery and appropriate development.

\section{The Role of Geography in Tourism Development Trajectories}

\section{Site: The Importance of Place}

Site refers to the physical characteristics of a location, such as soil types, topography, climate and other amenities. For Caribbean tourism the positive geographical site factors have been traditionally surmised as the tropical 'three S's' of abundant sunlight, attractive white sand beaches and azure seas (Davenport \& Jackiewicz 2008). For the first of these site factors, sun, the ideal tropical location ensures more direct incoming solar radiation than found in temperate latitudes while the Caribbean dry season with bright sunshine is a striking juxtaposition, albeit seasonally complementary, to the grey dreariness of winter in the major tourist markets in Europe and North America.

There are also regional differences in sunshine due to the orographic process of forced uplifting of warm and moist air masses, resulting in heavy precipitation on the windward slopes of mountains and islands. The higher Windward Islands of the Lesser Antilles (Figures 1,2) receive greater amounts of cloud and rainfall and, hence, less sunshine, than the lower elevation Leeward Islands. Orography also plays an important part in the internal sunshine offerings of the Greater Antilles whereby northeast coasts and mountains generate greater orographic effects while the southwestern coasts, in contrast, generally lie in the rain-shadow of the central mountains and, hence, are much drier while receiving greater amounts of sunshine. There is a compromise to be made for mass tourism, however, in that greater amounts of rain equate to more tropical green vegetation which many temperate tourists value as representing an idealized exotic 'Garden of Eden' (Grove 1995), as opposed to the dry tropical savannah landscapes of the southwestern coasts. As a result, we most often see mass tourism developments on the north coast of the Greater Antilles islands 


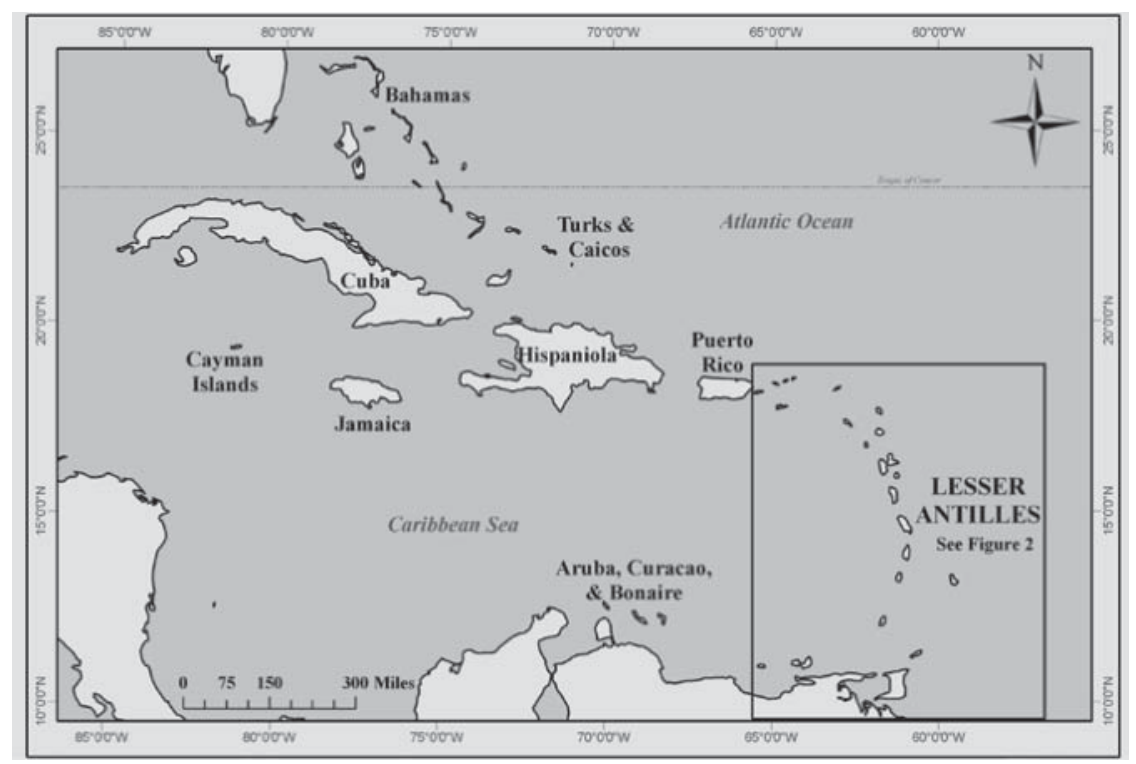

Figure 1. The Caribbean. Source: ESRI (2011).

which receive more rainfall than the southwest, yet have more sun than the northeast; in effect, striking a balance between sunshine and foliage.

The second of the three S's, attractive white sand beaches, is also due to the tropical location of the Caribbean's coral reefs. Over time, these reefs have been weathered, with the eroded coral creating elegant white sand beaches. Ideal beach availability also differs regionally, whereby the older Leeward Islands of the Lesser Antilles have had more time for coral reefs to be weathered and deposited as white sand beaches. The Windward Islands of the Lesser Antilles are younger and volcanic, with the mountainous terrain and higher precipitation amounts leading to greater deposition of eroded material from inland. The Windward Island of Dominica perhaps stands as the extreme example of the difference, with black sand beaches resulting from the volcanic origin of the island. In contrast, the Leeward Island of Antigua has extensive white sand beaches owing to its large coral reefs, which both provide white sand granules and protect the beaches from erosion.

The final of the 'three S' site factors, the azure Caribbean Sea, also owes its attractiveness and warmth to the tropical location. Typically, there is a preference for sites with shallow and calm water. Coral reefs not only help provide this, but offer diving opportunities and, as previously discussed, are responsible for the white sand beaches. Obviously, the interior of islands do not benefit from proximity to these attractive seashores, but even the coastlines vary in quality of sea conditions due to local geographies and their near-shore environments. For example, the coastlines 


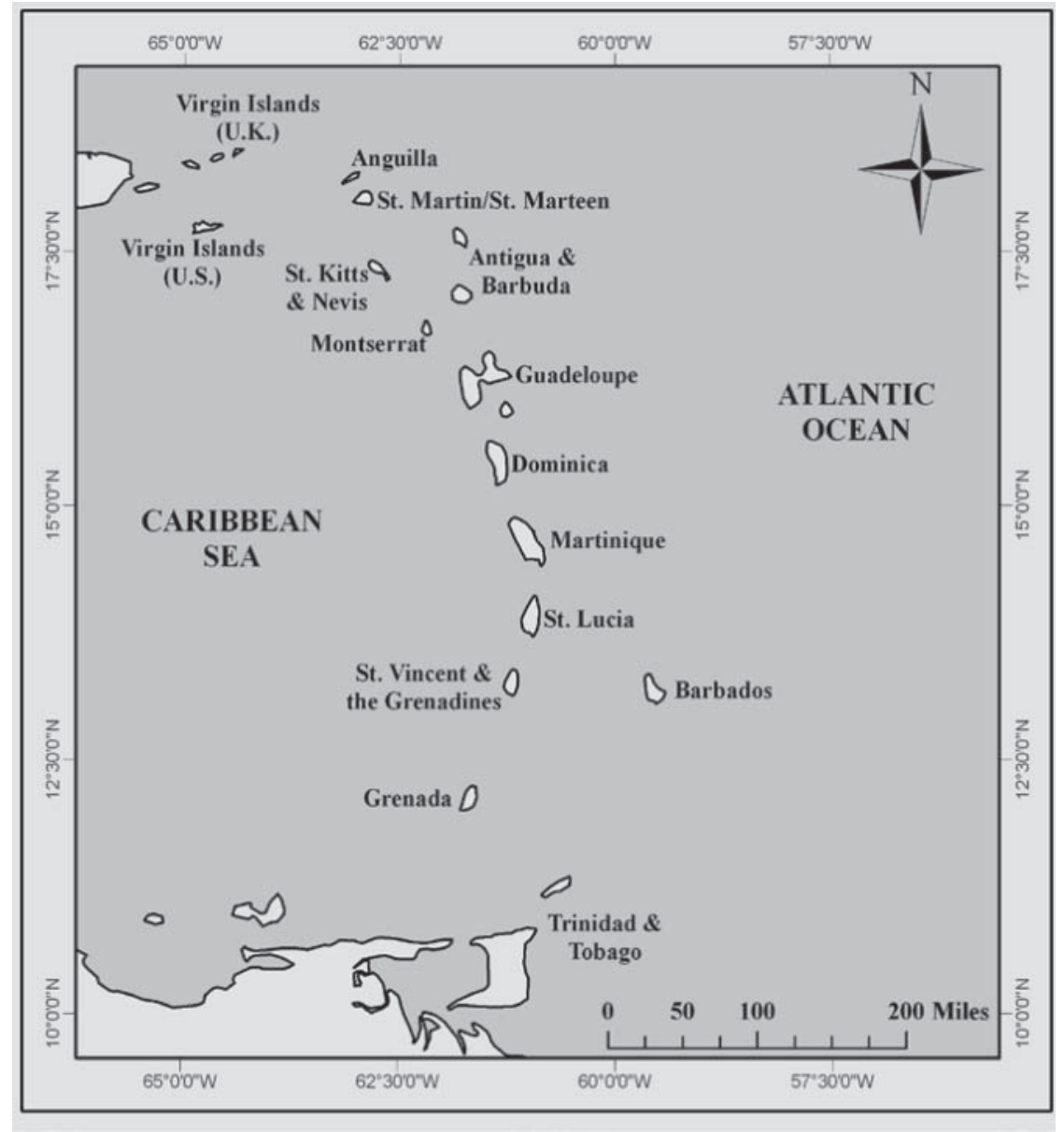

Figure 2. The Lesser Antilles. Source: ESRI (2011).

facing the Caribbean Sea tend to have more amenable conditions than those facing the Atlantic Ocean, which often are rougher and colder in water temperature.

There are compromises between all three of these physical site factors that contribute to the general pattern of mass tourism development in the Caribbean. In the Greater Antilles, mass tourism developments tend to occur on northern coastlines, where the aforementioned balancing of foliage and sunshine prevail. For the Windward Islands of the Lesser Antilles the majority of the mass tourism developments are on the west coast bordering the Caribbean Sea, and in a slight rain-shadow of the mountainous interiors. Even in the Leeward Islands, with few exceptions, the 
majority of mass tourism development also has occurred on the western coastlines that border the calmer, and warmer, Caribbean Sea.

\section{Situation: The Importance of Location}

Geographical situation factors, which refer to the location of a locale relative to another, are most applicable in terms of market accessibility and competition. For the Caribbean as a region the geographical proximity to the world's major tourist markets in North America and Europe place it at a great advantage over other tropical locations, such as Southeast Asia, the South Pacific or equatorial Africa. Within the Caribbean region, differences in geographical proximity exhibit distance decay whereby locales closest to the USA and, to a lesser degree, Europe attract the majority of tourists, while those further away receive less.

For example, the Greater Antilles dominate in absolute number of tourist arrivals, by a large margin. While the greater size of the Greater Antilles islands contributes to this trend, it is less of a factor for the islands of the Lesser Antilles as exhibited by the application of a tourism penetration index. This index consists of the number of hotel rooms per square kilometre, daily visitor density per 1,000 population and per capita visitor spending (McElroy \& de Albuquerque 1998). Recent data for the tourism penetration index showed that islands which lie closer to the US mainland, such as St Maarten, the Cayman Islands, the US and British Virgin Islands and Anguilla, have higher tourism penetration index scores than those lying further away, namely Trinidad and Tobago, Grenada, St Vincent and Dominica (Parry \& McElroy 2009) (Table 1).

Beyond the simplicities of geographical proximity lies the situation factor of connectivity; most notably direct air service from North America and Europe. Those lacking direct air service require an extra flight to connect, which increases time, cost and distance (Klak \& Flynn 2008). Direct air service for St Lucia has contributed to its higher tourism penetration index than neighbouring St Vincent or nearby Dominica, both of which lack this important accessibility factor (Conway \& Jemiolo 1991). Even within islands this holds true as areas close to, or easily accessible from, airports tend to have more developed tourist industries than outlying areas that are difficult or expensive to reach (Padilla \& McElroy 2005). One prime example of this intra-island accessibility function is Jamaica where the mass tourism industry on the north coast is connected internationally by the airport in Montego Bay and, internally, by the north coast highway. The southwestern coast lacks these situation amenities, which has limited the scope of tourism development there (Dodman 2009). Similarly, the Cedros Peninsula in the far south of Trinidad has always been a disadvantaged remote location without integration into the national settlement and highway systems, with a predictable lack of tourism development being one consequence.

The amenable geographical site and situation factors contribute to the selection of tourism development locations which, in a positive feedback loop, are prioritized 


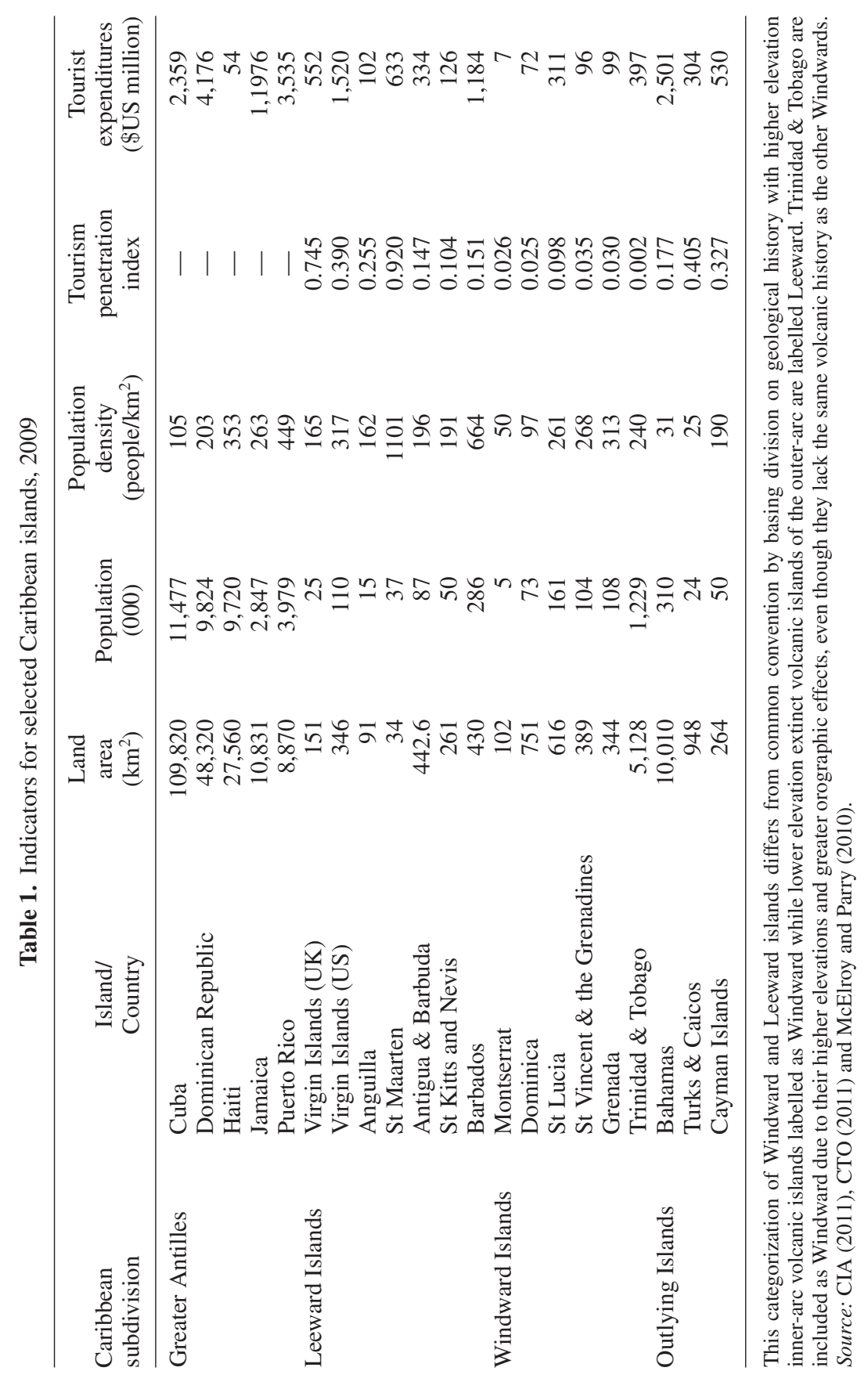


in infrastructure development leading to greater access and, hence, more tourism development. However, there is also a negative feedback loop in that increased mass tourism developments can lead to the previously discussed economic, social and environmental problems that detrimentally affect the tourism industry's health both in the short and long term (Butler 1980; 2004; de Albuquerque \& McElroy 1992).

\section{Marginality: Geographical Limitation or Advantage?}

Since the onset of mass tourism in the late 1960s and early 1970s, geographically marginal locations in the Caribbean, which are less endowed with the traditional amenable tourism site and situation factors, have commonly been overlooked by mass tourism developers and planners. Most islands' tourist industries have undergone growth and transformation so that just about all of them are in the later stages of their tourism life cycles (ECLAC 2008). Yet unevenness still prevails in most islands' tourism landscapes and geographically marginal locales now provide spaces for alternative forms of tourism to take root and develop; particularly in diverse, remoter locales in the Caribbean - be it ignored smaller islands or remote sections of larger ones. The time has come, then, to create and promote new models of sustainable tourism in these under-developed locales that maximize local benefits while avoiding the negative pitfalls so frequently attributed to mass tourism.

For example, ecotourism has become a prominent form of alternative tourism that is reliant on natural areas relatively undisturbed by human activities. It is partly because of their marginal locations, especially lack of accessibility, that a greater amount of 'pristine' nature remains (Timms 2008). And, in turn, it is this very marginality that has limited mass tourism development, leaving alternative tourism models such as ecotourism as the main options for these locales, as exemplified by Dominica (Weaver 1991; Klak \& Flynn 2008). Further, marginality plays a similar role within islands, such as the remoteness of the Toco-Matura-Grande Rivière region in the northeast of Trinidad, which has helped in the local development of a community co-managed ecotourism model centred on the preservation of breeding sites for the endangered leatherback turtle (James \& Fournillier 1993; Harrison 2007). However, it is important to note that the primary goal of ecotourism is environmental sustainability, although some proponents have argued for the inclusion of economic and social sustainability (Weaver 2004; Klak 2007).

Similarly, community-based tourism is reliant on maintaining and improving local community development (Milne \& Ewing 2004). Places like Treasure Beach, Jamaica, situated on the marginal southwest coast of the island, is an example where alternative tourism offerings are based on the attractiveness, hospitality and safety of the local community. Here the tourism industry, then, is a major stakeholder in maintaining, improving and promoting the local community through creating and funding community development groups, sponsoring health and youth sporting programmes, assisting fishing cooperatives and even organizing disaster relief assistance (Conway 
\& Timms 2010). Though this alternative tourism's social goals are focused on the local community, its reach does not implicitly include environmental sustainability.

The same applies to other alternatives as well, such as heritage tourism's defined focus on cultural attributes (Prentice 1993; Nuryanti 1996; Pulsipher 1999) and pro-poor tourism's defined interest in poverty reduction (Renard 2001; Torres \& Momsen 2004; Lewis \& Brown 2007). All of these alternative tourism models, which are attempting to maintain and/or improve local conditions in the face of increasing global pressures brought by modern industrial society, are related in their calls for sustainability. Following the Bruntland Commission's call, there is common agreement that environmental sustainability can be defined as the ability to "create economic and social benefit for now without sacrificing the well-being of future generations and the land on which they live' (Pattullo 2005: 246).

We would more explicitly include environmental sustainability while adding the concept of resilience to shocks - such as natural disasters or economic crises - to the definition. In order to achieve this latter refinement, we build upon Weaver's (2004: 440) definition of ecotourism whereby 'qualifying products must be primarily naturebased, focused on the provision of learning opportunities, and managed in such a way as to maximize the likelihood of environmentally and socio-culturally sustainable outcomes, including positive benefits for local communities'. This comprehensive and holistic definition accommodates and includes, rather than distinguishes between, a range of selected new tourism alternatives.

Adopting this definition as a starting point, we develop an inclusive alternative model titled 'slow tourism' that encompasses the environmental sustainability concerns of ecotourism, addresses the social and cultural sustainability interests of community-based tourism and pro-poor tourism, and advances economic sustainability ideals such as maximizing local linkages through agri-tourism. As such, slow tourism contributes to the advancement of the alternative tourism genre by coalescing the goals of these related tourism models through the adoption of Herman Daly's concept of 'soft growth' to philosophically identify, and combat, the core problems relating to the saturation of mass tourism resulting from its unsustainable hard growth axioms.

\section{Slow Tourism as an Alternative Genre}

\section{The Hard Growth of Mass Tourism}

At its core, slow tourism stands as the antithesis to mass tourism - with the latter focused on the economic growth paradigm leading to an improved Gross Domestic Product (GDP) through expanding market share. The adoption of neo-liberal economic capitalistic polices in the Caribbean has further encouraged the invitation of large-scale foreign-owned tourism developments to increase the numerical size of visitors and thereby provide material returns and monetary accumulations as a desired optimal consequence. For example, Jamaica's mass-tourism-dominated north 
coast has seen the addition of over 8,000 rooms solely from invited Spanish firms between 2001 and 2010 (JAMPRO 2010). In the spring of 2011, it opened a cruise ship terminal in Falmouth to accommodate the world's largest cruise ship to increase the number of day-trippers (Flemming 2011), even though they spend up to 17 times less than stay-over visitors (Potter et al. 2004).

Such massive tourism expansion demonstrates the modern capitalistic focus on what Herman Daly (1990) has labelled hard growth. Hard growth involves a continuous increase in size and scale, as exhibited by an economic focus on increasing GDP through increased production, which is eventually constrained by natural limits (Hall 2009). However, island ecosystems are limited in their ability to both provide natural resources for hard growth and to serve as an environmental sink for the generated waste (McElroy \& de Albuquerque 1991; Goodland 1992; Conway \& Lorah 1995). It is argued that the limits to hard growth have been surpassed in many of the region's islands based on the untenable axiom of an ever-growing economy based on hard growth in what are essentially closed ecosystems (Vitousek et al. 1995).

The reliance on these imported external inputs, along with foreign ownership of many mass tourism complexes, also facilitates capital leakage, with estimates ranging from 40 to 85 percent of tourist revenues leaving the islands (Potter et al. 2004; Pattullo 2005). Such importation also increases the pressure on the natural resource base by increasing the flow of matter and energy through the typical small island ecosystems, with waste disposal already becoming the most visible of problems in this regard. And, if the scale of impacts is broadened beyond individual Caribbean island ecosystems, the quantitative increase in tourist numbers also negatively affects the global environment. The vast majority of these increased tourists arrivals will do so via air transport, which increases carbon dioxide emissions (Hall 2009).

On a more philosophical level, mass tourism is also reflective of the socio-cultural changes that capitalist hard growth principles have prompted. While wealth generation has created a growing number of people with time for leisure, the quickening pace of activity is now shrinking both space and scarcity of time for leisure activities (Morello 2004). Further, this has created a focus on the quantity of leisure activity consumption in a shorter amount of time by a multitude of alienated, and alienating, mass tourist acolytes that 'mistake frenzy for efficiency' (Irving 2008: 44). Indeed, the mass commodification of tourists' leisure spaces is a result of time scarcity during holidays, as much as there are time-space compressions of the modern workday life (Harvey 1989). In sum, the hard growth paradigm of mass tourism has resulted in negative economic, environmental and social repercussions, which exhibit a lack of sustainability over the long term.

\section{Slow Tourism as a Soft Growth Alternative}

In light of the unsustainable nature of hard growth, Daly (1990) promotes an alternative of soft growth that entails qualitative improvements in efficiency. The difference between these two components is analogous to the difference between growth and development, whereby 'growth is a quantitative increase in physical scale, while 
development is qualitative improvement or unfolding of potentialities. An economy can grow without developing, or develop without growing, or do both, or neither' (Daly 1991: 402). Soft growth, then, is not directly dependent on the natural resource base nor on the external throughputs of the global industrial complex and commercial commodity chains. Instead, it promotes economic development, rather than mere growth, by relying on the use of local resources and increasing efficiency.

One cognizant, and specific, example of soft growth in response to massconsumptive society has been the slow food movement (Petrini 2001; Stille 2001; Kummer 2002; Irving 2008). In the same vein of thought as soft growth, slow food calls for a reversal in peoples' living practices in general, and their eating habits specifically, from the quickened pace of 'fast life' resulting from modern industrial society based on hard growth principles to one which emphasizes experience (quality) over mere consumption (quantity). This movement particularly targets 'fast food' as symbolic of the powerless position in which people find themselves in today's hectic and stressful world, with slow food preparation, organization and enjoyment symbolizing its antithesis (Pietrykowski 2004).

Slow food has spurred many other derivatives that are collectively referred to as the 'slow movement'. One salient offshoot is the advocacy of slow travel as an alternative to mass tourism's fast-paced, escapist vacation. Embracing similar sentiments to slow food's culinary focus, it concentrates on the enjoyment of the journey rather than just physical travel as a mode of transport to a destination. Gardner (2009: 11) expands upon this concept in claiming '[s]low travel engineers time, transforming it into a commodity of abundance rather than scarcity'. A similar derivative of the slow food movement's genesis is the concept of slow cities as an alternative approach to contemporary urban development (Mayer \& Knox 2006). Slow cities bring to the fore a focus on local resources, emphasizing social, cultural and economic strengths and the importance of region-based heritages. The movement aims to improve urban sustainability and address the interdependencies between the environment, economy and equity (Campbell 1996).

Building upon the slow food movement and its city and travel progeny, we propose a slow tourism derivative that combats the conundrum of time-space compression that mass tourism creates by advocating a return to more sustainable slow livelihoods based on savouring experience, rather than maximizing consumption. Further, borrowing from Gardner's (2009) slow travel notions, we reiterate that slow tourism also is about making the decision to slow down by enjoying the process of travel; in effect reversing time-space compression through creating quality time and benefitting from 'quality leisure', meeting the rising demand of a maturing cohort of more timeand experience-seeking travellers (Conway \& Timms 2010; Timms \& Neill 2011). Promotion of sustainability is also paramount, not only from an environmental perspective but also culturally by countering the loss of local distinctiveness as it relates to leisure, sense of place, and conviviality through understanding others' cultures and developing common interests between hosts and 'tourists as guests'. 
Economically, slow tourism aims to develop softly through reducing capital leakage as opposed to merely 'growing' a destination through increasing tourist arrivals. This increases tourism efficiencies through quality enhancements, such as local provisioning of agricultural products and beverages, handicrafts, furnishings and service activities. At the community and household levels, handicrafts, food production, service and retail stores, and a diverse assortment of locally owned and managed accommodation establishments provide much-needed income for the entrepreneurial minded. Being petty-commodity producers, such small informal sector operations have cost structures, economic relations and motivations based on familial and/or household relations (Wheelock 1992). It has been demonstrated that smaller locally owned tourism enterprises purchase a substantially larger percentage of their goods, such as food, from local sources than do large foreign-owned enterprises (Momsen 1998). While this is partly attributable to economies of scale for larger foreign-owned establishments, it also has to do with improved local relationships (Timms 2006).

Additionally, the focus on quality over quantity creates greater resilience to economic shocks through a community development focus and not tourism growth and development per se. Hence, productive activities are orientated toward local consumption patterns with tourism demand accommodated by responsive increases in production. And maximizing local multipliers contributes to diversified, articulated, resilient and less dependent local economies capable of reorientating production toward local needs during global economic shocks, such as global food crises, which creates a more competitive position for local farmers in relation to rising costs of imported foodstuffs (Timms 2009). In concert, the associated recent global economic recession and resultant decrease in visitor numbers and expenditures can be combated through such reorientation of production, be it agriculture or other sectors, toward domestic markets as rising import costs create an opportunity for local producers.

Such micro-economic flexible responses to marginality would also have positive impacts on social sustainability. In these complementary activities, the balance of social power and economic decision making shifts from the formal to the informal (complementary) economy. This can broaden rural household and family economic roles from activities dominated by men to incorporate activities managed by women as significant and important to household survival and reproduction (Momsen 1994). Further, they supplement household incomes, add flexibility to the survival strategies open to members, and help maintain rural farming endeavours, such as 'Antillean gardens', food-forest plots and smallholdings (Berleant-Schiller \& Pulsipher 1986; Hills 1988; Brierley 1991). Hence, the positive benefits of slow tourism's soft growth potential advances the interests of the under-privileged and powerless in the oftforgotten marginal villages and scattered communities, which addresses the goals of both community tourism and the poverty reduction aims of pro-poor tourism (Renard 2001; Torres \& Momsen 2004).

The adoption of soft growth importantly addresses, and is based upon, concerns over environmental sustainability. Capturing a greater share of capital spent by tourists 
allows destination economies to develop while minimizing the resource demands that increased numbers of tourists would require. Island ecological systems require greater conservation efforts, and the replacement of the hard growth maxims of mass tourism and its derivatives with soft growth policies and practices would contribute greatly to this cause (Conway \& Timms 2003). And, from a global environmental change perspective, maximizing the returns from small-scale tourism establishments as opposed to expanding the number of rooms in large resorts would reduce the potential carbon dioxide contributions of tourism by lowering the expansion of air travel service the latter would require (Hall 2009).

One caveat, however, is that the slow travel movement calls for the avoidance of air travel (whenever possible) and promotes slower and more environmentally friendly alternative modes of transport (Dickinson 2007). Unfortunately, Caribbean tourism is dependent on air travel and the alternative, cruise ships, lies outside the slow tourism paradigm of local inclusiveness and reducing capital leakage. Ferries and sailboat travel can be promoted, and included, in a slow tourism model but are quite limited in their scope, and certainly not a viable alternative to long-haul air travel to and from the main markets. But, as mentioned earlier, focusing on quality over quantity can partially counter, or ameliorate the rise in number of air passengers, reducing the environmental footprint (Hall 2010). Also, the Caribbean's greater proximity to major markets in Europe and the USA relative to other tropical destinations in Asia, the Pacific and Africa reduces the environmental impact from airline carbon dioxide emissions.

A second concern is that this localized small-scale slow tourism model cannot be the panacea for all of tourisms problems throughout the Caribbean region as a whole. Hall (2010) argues for the need of a global steady-state tourism, also based on Daly's (2008) work, but notes that it is not palpable at the moment to tourism planners. We agree in the context of mass tourism-saturated locales, although they can promote more soft forms of growth through focusing on maximizing returns from existing accommodation 'spaces' by filling unoccupied rooms and reducing seasonal variations in occupancy rates. More importantly, however, we also believe that our concept of slow tourism can be advanced in those geographically marginal locations where diversity persists and considerable potential awaits; and have argued this geographical and contextual aspect of uneven development earlier. It also needs to be stressed further that slow tourism encourages new ideas about how to grow locales in more conscious and measured ways so that inclusive alternatives are formed from the existing cultural hearths of local practice and communal/familial knowledge that have always existed in the many overlooked, marginal and out of the way peripheries of Caribbean islands.

\section{Implementing Slow Tourism in the Caribbean's Geographical Margins}

As discussed, it is geographically marginal locations in the Caribbean, and elsewhere for that matter, where alternatives to mass tourism, such as slow tourism, have available spaces for appropriate slow growth development. But without careful planning 
and implementation, slow tourism could very well serve as a 'Trojan horse', identifying and opening these areas to the hard growth axioms of mass tourism (Butler 1990). In some cases, this has been the experience of eco-tourism as it can be co-opted as a marketing product for mass tourism, resulting in environmental and socio-economic stress (Carrier \& Macleod 2005). Or, in another case, the 'disneyfication' of cultural tourism, such as is currently occurring in Falmouth, Jamaica, where historical Georgian architecture is being modernly retrofitted to appeal to the new influx of cruise ship visitors that the newly operational cruise ship terminal is now delivering. Therefore, we provide a few lessons for implementing slow tourism in geographically marginal locations based on the example of Treasure Beach, Jamaica (Figure 3). Treasure Beach is a loosely organized series of small fishing villages on the marginal southwest coast of the island. Lacking the relative geographical site and situation factors of easy accessibility, white sand beaches, tropical wet climate and associated vegetation and calm seas has limited its appeal to mass tourism developers and left it free to develop a unique form of alternative tourism that, while not specifically evolving with slow tourism as a specific goal, followed a trajectory based on slow tourism ideals (Hawkins 1999).

The first lesson is to keep tourism establishments small scale, with a focus on developing the quality of a locale as opposed to a focus on merely growing a locale. In order to do so, development must be carefully planned and managed, which

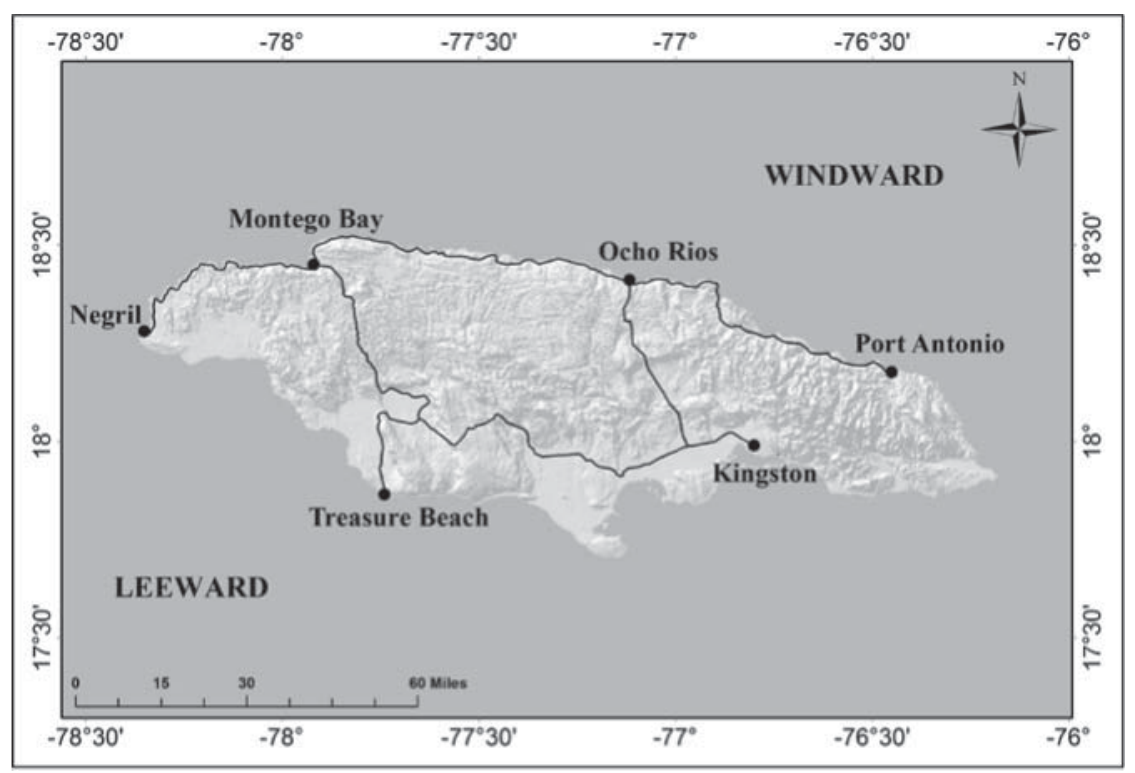

Figure 3. Jamaica's major tourist sites, roads and topography. Source: ESRI (2011). 
requires cooperative partnerships between local stakeholders and local government planning efforts (Scheyvens \& Momsen 2008). In the past two decades, neo-liberal restructuring has forced states to focus on hard growth promotion of mass tourism, but has also called for decentralization of government functions to the local level that is argued to address more appropriately local situations and concerns (Ribot 2004). Social scientists tend to agree, and have long advocated for empowering local communities in development decision making and management, particularly as they are the proximate stakeholders in its success (Ostrom 1990; Conway \& Timms 2003). In Treasure Beach this has resulted in local legislation limiting tourist accommodations to 15 rooms per acre (half the density for Jamaica as a whole) to deliberately exclude mass tourism development. Further, local stakeholders in Treasure Beach's tourism industry have fought to limit the scale of expansion of water utilities to an adjacent area targeted for mass tourism development for the same purpose (Jason Henzell, personal communication, 2007). Such targeted planning is essential to ensure that tourism development is guided and controlled to reflect local concerns, and minimizes environmental pressures on the local resource base.

A second related lesson is to keep the control of slow tourism local to ensure that benefits accrue to local communities through tourism multipliers, and not let it be repatriated abroad, which is more likely with larger foreign-owned tourism enterprises (Momsen 1998; Timms 2006). The vast majority of tourism establishments in Treasure Beach are owned and run by local families, including restaurants, accommodations and tour operators. These locally owned establishments procure much of their supplies locally from fishing cooperatives, farming cooperatives and markets, and craftspeople. Even the small resort Jake's in Treasure Beach, which recently became part of the larger Chris Blackwell's consortium Island Outpost, has developed relationships with the local agricultural cooperative, Treasure Beach Ital Farmers Association. It purchases seafood from local fishermen, meats from local ranchers and uses local building materials and workers as an intentional strategy to develop the local community (Jason Henzell, personal communication, 2007). Hence, a greater percent of the tourist's expenditures remain in the local community, stimulating the local economy and spreading benefits more equitably.

A third suggestion is to include a diversity of establishments at multiple price points to promote democratization of the benefits of a slow tourism product. The importance of this diversity increases the possible sources of tourists and encourages more small-scale local establishments (Timms \& Neill 2011). One concern of alternative tourism is the limited, and specific, demand for these offerings that can be considered elitist (Whelan 1991). However, in Treasure Beach there is a variety of tourism establishments, including higher-end chic small resorts and villas, mid-priced guesthouses and even budget backpacker establishments, which attract a diversity of visitors that seek out a more community-orientated tourism experience while combating critiques of elitism in alternative tourism. Further, Treasure Beach has created its own web-portal that promotes a slower tourism product, including searches for 
local accommodations, restaurants, tour operators, and serves as a web presence for local community development organizations and schools (TreasureBeach.net 2011).

This last point relates to our final lesson, the slow tourism product should be a true partnership with the local community that develops the quality of tourism and local community symbiotically and reinforces the slow growth focus on development over growth. In Treasure Beach this is accomplished in several ways, including the aforementioned web-portal that benefits both tourism and community. One specific example for Treasure Beach is the donation of $\$$ US1 for every occupied hotel room to local community development groups that promote health and literacy campaigns, sponsor local sports teams and even provide disaster relief assistance, as occurred after Hurricane Ivan in 2004 and Hurricane Dean in 2007 (Conway \& Timms 2010). Since the slow tourism model has a stake in the local community, the benefits of slow tourism contributed back to ensure a thriving local community as it is part of the slow tourism product. Other examples of such soft growth slow tourism in marginal locales in the Caribbean await study, and promotion, to test and develop our theoretical claims (Conway \& Timms 2010). As the concept of slow tourism is still in its early stages of development, it is a prime topic for more research and development.

\section{Conclusions}

Geographical marginality and the geographical dimensions of place disadvantages, which can be recast for alternative tourisms' advantage, have not been considered previously as important considerations in the evolution and maturation of Caribbean tourism industrial mixes. With many Caribbean islands' tourism life cycles being in their latter stages (ECLAC 2008), and in need of revitalization and renewal if they are not to founder and become stagnant, as Butler's (2004) TALC general model predicts, it behoves planners and tourism promoters in the Caribbean to recognize the value and necessity of encouraging the widening of their tourism sector's diversity to include new and appropriate tourism forms that are more sustainable economically, socially and environmentally. Here we argue that slow tourism can serve this goal in marginal locations through its philosophical basis in slow growth development.

Being practical and realistic about the difficulties of launching slow tourism in such previously overlooked and underdeveloped locales, the modest pace and limited scale of development of slow tourism that we envisage occurring will limit its ability to be the panacea for all of the Caribbean tourism industry ills. However, it can be a partner to many Caribbean islands' conventional sun, sand and sea tourism offerings to not only provide a more comprehensive tourism product (Timms \& Neill 2011), but ameliorate the often-produced uneven landscapes that mass tourism's penetration has caused, or exacerbated (Scheyvens \& Momsen 2008). Slow tourism initiatives in the remoter locales can also serve as a model for other forms of new tourism alternatives by adopting soft growth forms of development (Conway \& Timms 2010). 
Further, lessons learned from slow tourism could influence the adoption of more soft growth practices for the mass tourism industry as well, decreasing its negative economic, social and environmental impacts while maximizing local benefits. For example, instead of building more rooms or adding more cruise-ship terminals, Caribbean islands can maximize the benefits of their existing tourism capacities and its supportive infrastructure while at the same time seeking to address the unevenness of regional economic well-being that commonly persists even in the smallest of islands. Cutting down on capital leakage and stimulating local enterprises is a worthwhile goal which carries tremendous potential to grow local economies in a more socially, economically, and environmentally sustainable manner (Timms 2006). The current volatility in the global economic order, and the failure of neo-liberalism to overcome the inevitable structural crises that plunge such capitalist geo-economic systems into severe downturns (Harvey 2003), shows that there is an even greater need to find more sustainable forms of tourism in the Caribbean that stimulate local economies and are less vulnerable to external market shocks than the current hard growth mass tourism industry (Timms 2009).

One final reflection deserves noting in regards to this re-evaluation of the Caribbean tourism industry and our advocacy of a place in the future mix for slow tourism. Common, if despondent, findings of early tourist development models envisaged three stages of evolution with the possibility of the final stage dominated by mass tourism stagnation and its associated negative social, economic and environmental consequences (Butler 1980; de Albuquerque \& McElroy 1992; McElroy \& de Albuquerque 1998). Importantly, however, McElroy and de Albuquerque (2002) remind us that it is unfettered hard growth beyond the second transitional stage of tourist penetration and rapid expansion into the third saturation stage that bodes ill for Caribbean tourisms' continued vitality.

We argue that geographically marginal locations, both regionally and within islands, that have yet to progress past the first or second stages, are prime locations to disregard quantitative hard growth development and adopt the quality of soft growth development through slow tourism. In order to do so, however, the development of slow tourism must be carefully planned and managed with the full participation of local stakeholders. And, this entails government and legislative support (Scheyvens \& Momsen 2008), such as the cooperative partnership that occurred in Treasure Beach, Jamaica. If not, the slow tourism brand could very well be co-opted as a marketing tool for the mass tourism industry to employ in capturing a niche market and develop along the rather uncontrollable, evolutionary trajectories of past explanatory models.

Slow tourism, based on the slow movement's philosophical bases and following a soft growth trajectory, stands as the antithesis to mass tourism as potentially sustainable socially, economically and environmentally. Hence, it coalesces the goals of many other alternative tourisms - the environmental prospects of ecotourism (Weaver 2004; Klak 2007), the poverty-reduction goals of pro-poor tourism (Torres \& Momsen 2004), the linkage-induced stimulation effects of agri-tourism (Momsen 
1998; Collins 2000; Timms 2006), the cultural aspects of heritage tourism (Pulsipher 1999), the egalitarian efforts of community tourism (Milne \& Ewing 2004), amongst others. The generalizable strength of its humanistic ethical position lies in its stress on quality considerations rather than quantity realizations. The former, therefore, becomes the preferred way forward for all stakeholders through advancing soft growth over hard growth and focusing on the adoption of this alternative, participatory, inclusive model in geographically marginal locations throughout the Caribbean (Conway \& Timms 2010). As such, it caters to the growing numbers of contemporary globally experienced tourists who are seeking a heightened quality of life in their visits that offers variety, uniqueness and thorough enjoyment in the easy-paced, and local community tourism leisure-environments without imposing undue demands on their local host communities as their guests. Indeed, it moves the focus of tourism back to the 'original meaning of words such as 'holidays' (holy days), 'vacances' (in French, 'empty days') or 'recreation' (Matos 2004: 96).

\section{References}

Baldwin, J. (2000) Tourism development, wetland degradation and beach erosion in Antigua, West Indies, Tourism Geographies, 2(2), pp. 193-218.

Berleant-Schiller, R. \& Pulsipher, L. D. (1986) Subsistence cultivation in the Caribbean, New West Indies Guide, 3(1), pp. 1-40.

Boruff, B. J. \& Cutter, S. L. (2007) The environmental vulnerability of Caribbean island nations, Geographical Review, 97(1), pp. 24-45.

Brierley, J. S. (1991) Kitchen gardens in the Caribbean, past and present: their role in small farming development, Caribbean Geography, 3(1), pp. 15-28.

Butler, R. W. (1980) The concept of a tourist area cycle of evolution: implications for management of resources, Canadian Geographer, 24(1), pp. 5-12.

Butler, R.W. (1990) Alternative tourism: pious hope or Trojan horse?, Journal of Travel Research, 28(3), pp. 40-45.

Butler, R. W. (2004) The tourism area life cycle in the twenty-first century, in: A. A. Lew, C. M. Hall \& A. M. Williams (Eds) A Companion to Tourism, pp. 159-169 (New York: John Wiley).

Campbell, S. (1996) Green cities, growing cities, just cities? Urban planning and the contradictions of sustainable development, Journal of the American Planning Association, 62(3), pp. 296-312.

Caribbean Tourism Organization (CTO) (2011) Statistics and market research. Available at http://www. onecaribbean.org/statistics/countrystats/ (accessed 1 February 2011).

Carrier, J. \& Macleod, D. V. L (2005) Bursting the bubble: the socio-cultural context of ecotourism, Royal Anthropological Institute, 11, pp. 315-334.

Central Intelligence Agency (CIA) (2011) The world factbook. Available at https://www.cia.gov/library/ publications/the-world-factbook/index.html (accessed 1 February 2011).

Collins, P. (2000) Agro-tourism - a sustainable approach to economic growth, in: Proceedings: Agrotourism Conference, Trinidad and Tobago, Inter-American Institute for Co-operation in Agriculture.

Commonwealth Secretariat (1991) Sustainable Development: An Imperative for Environmental Protection (London: Economic Affairs Division, Commonwealth Secretariat).

Conway, D. (1993) The new tourism in the Caribbean: reappraising market segmentation, in: D. Gayle \& J. Goodrich (Eds) Tourism Marketing and Management in the Caribbean, pp. 167-177 (London: Routledge). 
Conway, D. \& Jemiolo, J. (1991) Tourism, air service provision and patterns of Caribbean airline offer, Social and Economic Studies, 40(2), pp. 1-45.

Conway, D. \& Lorah, P. (1995) Environmental protection policies in Caribbean small islands: some St. Lucia examples, Caribbean Geography, 6(1), pp. 16-27.

Conway, D. \& Timms, B. F. (2003) Where is the environment in Caribbean development thinking and praxis?, Global Development Studies, 3(1-2), pp. 91-130.

Conway, D. \& Timms, B. F. (2010) Re-branding alternative tourism in the Caribbean: the case for 'slow tourism', Tourism and Hospitality Research, 10(4), pp. 1-16.

Daly, H. E. (1990) Sustainable growth: an impossibility theorem, Development, 3/4, pp. 45-47.

Daly, H. E. (1991) Sustainable growth: A bad oxymoron, Environment and Carcinogenic Reviews, 8(2), pp. 401-407.

Daley, H. E. (2008) A Steady-State Economy (London: Sustainable Development Commission).

Davenport, J. \& Jackiewicz, E. L. (2008) Spaces of tourism, in: E. Jackiewicz \& F. Bosco (Eds) Placing Latin America: Contemporary Themes in Human Geography, pp. 97-113 (Lanham, MD: Rowman $\&$ Littlefield).

de Albuquerque, K. \& McElroy, J. L. (1992) Caribbean tourism styles and sustainable strategies, Environmental Management, 16, pp. 615-632.

Dickinson, J. (2007) Slow Tourism Travel for a Lower Carbon Future. Available at http://www. bournemouth.ac.uk/icthr/PDFs/rgs_report.pdf (accessed 31 August 2009).

Dodman, D. (2009) Globalization, tourism and local living conditions on Jamaica's north coast, Singapore Journal of Tropical Geography, 30(2), pp. 204-219.

Duval, D. T. \& Wilkinson, P. F. (2004) Tourism development in the Caribbean: meaning and influences, in: D. Duval (Ed.) Tourism in the Caribbean: Trends, Development, Prospects, pp. 59-80 (London: Routledge).

Economic Commission for Latin America and the Caribbean (ECLAC) (2008) Tourism Life Cycle, Tourism Competitiveness, and Upgrading Strategies in the Caribbean (Port of Spain, Trinidad and Tobago: ECLAC).

ESRI (Environmental Systems Resource Institute) (2011) ArcMap 10 (Redlands, CA: ESRI).

Flemming, B. (2011) Falmouth Pier Docks History, Jamaica Gleaner, 19 February 2011. Available at http://jamaica-gleaner.com/gleaner/20110219/news/news1.html (accessed 29 March 2011).

Gardner, N. (2009) A manifesto for slow travel, Hidden Europe, 25, pp. 10-14.

Goodland, R. (1992) The case that the world has reached its limits: More precisely that current throughput growth in the global economy cannot be sustained, Population \& Environment, 13(3), pp. 167-182.

Grove, R. H. (1995) Green Imperialism: Colonial Expansion, Tropical Island Edens and the Origins of Environmentalism, 1600-1860 (Cambridge: Cambridge University Press).

Hall, C. M. (2009) Degrowing tourism: décroissance, sustainable consumption and steady-state tourism, Anatolia: An International of Tourism and Hospitality Research, 20(1), pp. 46-61.

Hall, C. M. (2010) Changing paradigms and global change: from sustainable to steady-state tourism, Tourism Recreation Research, 35(2), pp. 131-145.

Harrison, D. (2007) Cocoa, conservation and tourism: Grande Rivière, Trinidad, Annals of Tourism Research, 34(4), pp. 919-942.

Harvey, D. (1989) The Condition of Postmodernity (Oxford: Basil Blackwell).

Harvey, D. (2003) The New Imperialism (Oxford: Oxford University Press).

Hawkins, M. (1999) Tourism and place in Treasure Beach, Jamaica: imagining paradise and the alternative, Doctoral Dissertation, Department of Geography, Louisiana State University.

Hills, T. (1988) The Caribbean food-forest: ecological artistry or random chaos?, in: J. S. Brierley \& H. Rubenstein (Eds) Small Farming and Peasant Resources in the Caribbean, pp. 1-28 (Winnipeg, Canada: Department of Geography, University of Manitoba).

Irving, J. (2008) Welcome to Our World: Companion Slow Food. Available at http://www.slowfoodusa. org/downloads/local_chapter_resources/COMPANION_ENG.PDF (accessed 16 September 2011). 
Jamaica Promotions Corporation (JAMPRO) (2010) Look out Dubai, here's Jamaica! Available at http://www.jamaicatradeandinvest.org/index.php?action=investment $\&$ id=34\&oppage=5\&opid=6 (accessed 26 August 2010).

James, C. \& Fournillier, K. (1993) Marine Turtle Management in Northeast Trinidad - A Successful Community Based Approach towards Endangered Species Conservation (Laventille, Trinidad Tobago: Forestry Division, Government of Trinidad and Tobago).

Klak, T. (2007) Sustainable ecotourism development in Central America and the Caribbean: Review of debates and conceptual reformulation, Geography Compass, 1(5), pp. 1037-1057.

Klak, T. \& Flynn, R. (2008) Sustainable development and ecotourism: general principles and an Eastern Caribbean case study, in: E. L. Jackiewicz \& F. J. Bosco (Eds) Placing Latin America: Contemporary Themes in Human Geography, pp. 115-136 (Lanham, MD: Rowman \& Littlefield).

Kummer, C. (2002) The Pleasures of Slow Food (San Francisco: Chronicle Books).

Lewis, A. \& Brown, T. (2007) Pro-poor tourism: a vehicle for development in Trindad and Tobago. Paper presented at the Conference in Crisis, Chaos and Change: Caribbean Development Challenges in the 21st Century, St Augustine, Trinidad and Tobago.

Maingot, A. P. (1994) The United States and the Caribbean: Challenges of an Asymmetrical Relationship (Boulder: Westview Press).

Matos, R. (2004) Can slow tourism bring new life to alpine regions?, in: K. Weiermair \& C. Mathies (Eds) The Tourism and Leisure Industry: Shaping the Future, pp. 93-103 (New York: The Haworth Hospitality Press).

Mayer, H. \& Knox, P. L. (2006) Slow cities: sustainable places in a fast world, Journal of Urban Affairs, 28(4), pp. 321-334.

McElroy, J. L. \& de Albuquerque, K. (1991) Tourism styles and policy responses in the open economyclosed environment context, in: N. P. Girvan \& D. Simmons (Eds) Caribbean Ecology and Economics, pp. 143-165 (Barbados: Caribbean Conservation Association).

McElroy, J. L. \& de Albuquerque, K. (1998) Tourism penetration index in small Caribbean islands, Annals of Tourism Research, 25(1), pp. 145-168.

McElroy, J. L. \& de Albuquerque, K. (2002) Problems for managing sustainable tourism in small islands, in: Y. Apostolopoulos \& D. J. Gayle (Eds) Island Tourism and Sustainable Development: Caribbean, Pacific and Mediterranean Experiences, pp. 15-31 (London: Praeger).

McElroy, J. L. \& Parry, C. E. (2010) The characteristics of small island tourist economies, Tourism and Hospitality Research, 10(4), pp. 315-328.

Milne, S. \& Ewing, G. (2004) Community participation in Caribbean tourism: problems and prospects, in: D. T. Duval (Ed.) Tourism in the Caribbean: Trends, Development, Prospects, pp. 205-217 (London: Routledge).

Momsen, J. H. (1994) Tourism, gender and development in the Caribbean, in: V. Kinnaird \& D. Hall (Eds) Tourism: A Gender Analysis, pp. 106-120 (New York: John Wiley).

Momsen, J. H. (1998) Caribbean tourism and agriculture: new linkages in the global era?, in: T. Klak (Ed.) Globalization and Neoliberalism: The Caribbean Context, pp. 115-134 (Lanham, MD: Rowman \& Littlefield).

Morello, G. (2004) Spacing and timing in leisure activities, in: K. Weiermair \& C. Mathies (Eds) The Tourism and Leisure Industry: Shaping the Future, pp. 69-81 (New York: The Haworth Hospitality Press).

Nuryanti, W. (1996) Heritage and postmodern tourism, Annals of Tourism Research, 23(2), pp. 249-260.

Ostrom, E. (1990) Governing the Commons: The Evolution of Institutions for Collective Action (Cambridge: Cambridge University Press).

Padilla, A. \& McElroy, J. L. (2005) The tourism penetration index in large islands: the case of the Dominican Republic, Journal of Sustainable Development, 13(4), pp. 353-372.

Parry, C. E. \& McElroy, J. L. (2009) The supply determinants of small island tourist economies, The ARA (Caribbean) Journal of Tourism Research, 2(1), pp. 13-22. 
Pattullo, P. (2005) Last Resorts: The Cost of Tourism in the Caribbean (London: Cassell Latin American Bureau).

Pelling, M. \& Uito, J. I. (2001) Small island developing states: natural disaster vulnerability and global change, Environmental Hazards, 3(2), pp. 49-62.

Petrini, C. (2001) Slow Food: The Case for Taste (New York: Columbia University Press).

Pietrykowski, B. (2004) You are what you eat: the social economy of the slow food movement, Review of Social Economy, 62(3), pp. 307-321.

Potter, R. B., Barker, D., Conway, D. \& Klak, T. (2004) The Contemporary Caribbean (Harlow, UK: Pearson Education Limited).

Prentice, R. (1993) Tourism and Heritage Attraction (London: Routledge).

Pulsipher, L. M. (1999) 'Here where the old-time people be': reconstructing the landscapes of the slavery and post-slavery era in Montserrat, West Indies, in: J. B. Haviser (Ed.) African sites: Archaeology in the Caribbean, pp. 9-37 (Princeton, NJ: Markus Wiener).

Renard, Y. (2001) Practical Strategies for Pro-poor Tourism: A Case Study of the St. Lucia Heritage Tourism Programme (London: Overseas Development Institute).

Rhiney, K. (2009) Towards a new model for improved tourism-agriculture linkages? The case of two farmers' co-operatives in Jamaica, Caribbean Geography, 15(2), pp. 142-159.

Ribot, J. C. (2004) Waiting for Democracy: The Politics of Choice in Natural Resource Decentralizations (Washington: World Resources Institute).

Scheyvens, R. \& Momsen, J. H. (2008) Tourism and poverty reduction: issues for small island states, Tourism Geographies, 10(1), pp. 22-41.

Stille, A. (2001) Slow food: An Italian answer to globalization, The Nation, August, 21/27, pp. 11-16.

Thomas, G. A. (1991) The gentrification of paradise: St. John's Antigua, Urban Geography, 12(5), pp. 469-487.

Timms, B. (2006) Caribbean agriculture-tourism linkages in a neoliberal world: problems and prospects for St. Lucia, International Development Planning Review, 28(1), pp. 35-56.

Timms, B. (2008) The parallax of landscape: situating Celaque National Park, Honduras, in: D. C. Knudsen, M. M. Metro-Roland, A. K. Soper \& C. E. Greer (Eds) Landscape, Tourism, and Meaning, pp. 95-108 (Aldershot, UK: Ashgate).

Timms, B. (2009) Development theory and domestic agriculture in the Caribbean: recurring crises and missed opportunities, Caribbean Geography, 15(2), pp. 101-117.

Timms, B. \& Neill, S. (2011) Cracks in the pavement: conventional constraints and contemporary solutions for linking agriculture and tourism in the Caribbean, in: R. Torres \& J. Momsen (Eds) Tourism \& Agriculture: New Geographies of Consumption, Production, and Rural Restructuring, pp. 104-116 (London: Routledge).

Torres, R. \& Momsen, J. H. (2004) Challenges and potential for linking tourism and agriculture to achieve pro-poor tourism objectives, Progress in Development Studies, 4, pp. 294-318.

TreasureBeach.net. (2011) Homepage. Available at http://treasurebeach.net/guide/ (accessed 19 January 2011).

Vitousek, P. M., Loope, L. \& Andersen, H. (1995) Islands: Biological Diversity and Ecosystem Function (Berlin: Springer-Verlag).

Walsh, R. P. D. (1998) Climatic changes in the Eastern Caribbean over the past 150 years and some implications in planning sustainable development, in: D. F. M. McGregor, D. Barker \& S. LloydEvans (Eds) Resource Sustainability and Caribbean Development, pp. 51-68 (Kingston, Jamaica: The University of the West Indies Press).

Watts, D. (1995) Environmental degradation, the water resource and sustainable development in the Eastern Caribbean, Caribbean Geography, 6(1), pp. 2-15.

Weaver, D. B. (1991) Alternative to mass tourism in Dominica, Annals of Tourism Research, 18, pp. 414-432. 
Weaver, D. B. (2004) Manifestations of ecotourism in the Caribbean, in: D. T. Duval (Ed.) Tourism in the Caribbean: Trends, Development, Prospects, pp. 172-186 (London: Routledge).

Wheelock, J. (1992) The household in the total economy, in: P. Ekins \& M. Max-Neef (Eds) Real-life Economics: Understanding Wealth Creation, pp. 124-135 (London: Routledge).

Whelan, T. (Ed.) (1991) Nature Tourism (Washington, DC: Island Press).

Wilkinson, P. F. (1999) Caribbean cruise tourism: Delusion? Illusion?, Tourism Geographies, 1(3), pp. 261-282. 